\title{
The role of knowledge management processes on organizational culture
}

Joanna Paliszkiewicz, Warsaw University of Life Sciences - SGGW, Poland, joanna_paliszkiewicz@sggw.pl

Salome Svanadze, Ilia State University, Georgia, salome.svanadze.1@iliauni.edu.ge

Mariam Jikia, Georgian Technical University, Georgia, marijiqia@gmail.com

\begin{abstract}
This study sought to investigate which of the four predictor variables (Applying Knowledge, Storing Knowledge, Acquiring Knowledge, \& Diffusing Knowledge) are most significant in association with Organizational Culture. The instrument used in this study includes five parts that were used to measure the knowledge management processes (knowledge acquisition, storage, diffusion, \& application) and organizational culture. The instrument was administered to 77 employees from two of the largest Georgian cities: Tbilisi and Kutaisi. Collected data were analyzed through multiple regression analysis. The analysis was conducted to determine which of the independent variables (Acquiring Knowledge, Storing Knowledge, Diffusing Knowledge, \& Applying Knowledge) is significant in predicting the dependent variable (Organizational Culture). Diffusing Knowledge was found to be the only significant variable associated with the Organizational Culture. The analyses were followed by results, discussion, and implication for future research.
\end{abstract}

Keywords: knowledge management, organizational culture, knowledge acquisition, knowledge storage, knowledge diffusion, knowledge application

\section{Introduction}

Knowledge management has become a very popular topic in both academic and practical fields (Davenport \& Prusak, 1998; Koohang, Paliszkiewicz, \& Gołuchowski 2017; Liebowitz, 2008, 2012, 2016; Nonaka \& Takeuchi 1995; Paliszkiewicz 2007; Shveiby 1987). Knowledge has become the major competitive resource (Drucker, 1993) and a vital source of creative capability and strategic flexibility (Stacey, 2000; von Krogh \& Roos, 1995). In literature, there is a lot of research related to knowledge management and knowledge creation (Nonaka, 1994; Nonaka \& Takeuchi, 1995; von Krogh, Ichijo, \& Nonaka, 2000), sharing of knowledge (Dixon, 2000; Howells, 1996; Gilbert \& Cordey-Hayes, 1996; Paliszkiewicz \& Koohang 2013), organizational learning (Argyris \& Schon, 1978; Duncan \& Weiss, 1979). In this paper, we limit the topic to the relation between knowledge management processes and organizational culture.

The link between organizational culture and knowledge management has been a subject of many research (Al Saifi, 2015; Bozorgi, Khalili, \& Khalili, 2013; Dilmaghani, Fahimnia, Ardakan, \& Naghshineh, 2015; Lopez, Peon \& Ordas, 2004; McDermott \& O’Dell, 2001; Rai 2011; Tseng, 
2010; Zheng, 2009). The role of knowledge management in organizational culture was not studied in relations to four processes: applying, storing, acquiring, and diffusion of knowledge.

The purpose of this study was to investigate which of the four associated variables (applying knowledge, storing knowledge, acquiring knowledge, \& diffusing knowledge) is most significant in being associated with Organizational Culture. This paper is organized in a manner consistent with its purpose. First, the research background and the review of literature present the concept of knowledge management (four processes were described: knowledge acquisition, knowledge diffusion, knowledge application, \& knowledge storage), also an organizational culture in the context of knowledge management is described. Secondly, the research methodology is presented following the results of the study. Discussion, summary, and implication for the future research provided at the end of the paper.

\section{Research Background and Literature Review}

\section{Knowledge Management}

Knowledge can be defined as justified true beliefs (Nonaka, 1994), and can reside in individuals as well as collectively in the organization. It can be considered as an organizational resource based on employees' skills and experiences, the way it is managed and used will determine its advantages to the organization. Knowledge management is focused on providing the conditions under which knowledge could be acquired, diffuse, applicable, and storage for the attainment of organizational goals (Alavi \& Leidner, 1999; Drucker, 2001; Magnier-Watanabe \& Senoo, 2010).

\section{Knowledge Acquisition}

Knowledge acquisition is a process of obtaining new knowledge (Huber 1991) and recognizing existing knowledge. It involves a capability to recognize and acquire information from different sources. This occurs at both individual and group levels (Rusly, Corner, \& Sun, 2012). It is a very important way for companies to gain access to new knowledge and capabilities (Amiryany, Huysman, Ard-Pieter, \& Cloodt, 2012). According to Sun and Anderson (2010), "acquisition is created by socio - psychological process of individuals' intuition and interpretation" (p. 142).

Knowledge can be acquired from internal and external sources. Internal knowledge acquisition focuses on seeking knowledge from personal networks, employees' expertise and experience and organizational routines (Fong \& Lee, 2009; Ryu, Kim, Chaudhury, \& Rao, 2005; Yang \& Farn, 2010). Internal sources are related with intellectual capital of members of organizations. It can also involve the observation and examination of best practices, which requires employees' expertise to identify relevant knowledge for the organization. Knowledge can also be acquired externally from the firm's environment (policymakers, suppliers, \& clients) (Andreeva \& Kianto, 2011; Liu, 2010), recruitment of external experts, benchmarking and collaboration through business alliances (Fong \& Lee, 2009; Kim \& Lee, 2010; Liu \& Liu, 2008). One of the examples to acquire external knowledge is to buy other companies to gain new knowledge and capabilities, while it is common among high-tech companies. But, acquiring a firm does not guarantee that valuable knowledge will be successfully shared (e.g. Bresman, Birkinshaw, \& Nobel, 2010). According to Inkpen, Sundaramanant, and Rockwood (2000), value creation through acquisition 
is difficult and some researchers like Puranam, Singh, and Zollo (2003) have demonstrated that failure rates in high-tech acquisitions may reach between $60 \%$ to $80 \%$. Vermeulen and Barkema (2001) confirmed that acquisition usually has implementation and post- acquisition performance problems. Knowledge acquisition can arise from the direct experience of the organization and its members (Fiol \& Lyles, 1985; Huber, 1991). It can result from organizational members sharing experiences and prior learning (Lyles \& Schwenk 1992; Prahalad \& Bettis 1986). The top managers play very important role in the process of acquiring the knowledge (Lyles \& Salk, 2007).

\section{Knowledge Diffusion}

In order to realize the value of knowledge, the knowledge that is acquired by organizations needs to be continuously and effectively disseminated, applied, and used throughout the organization. Dissemination involves the behavior of the learner sharing acquired knowledge expertise and skills with other members of the organization, which occurs in interactions at individual, group and organizational levels (Bock, Zmud, \& Kim, 2005; Liao, Wu, Hu, \& Tsui, 2010; Lin \& Lee, 2006; Yi, 2009).

The main purpose of the knowledge diffusion in the organization is primarily to transfer the tangible or intangible knowledge that is preserved by members to the one who lacks (Huang, Chiu-Chi, \& Wei-Kou, 2007). Knowledge initially resides in an individual. Thus, an individual's willingness to share his or her knowledge with others and motivation to learn is necessary for knowledge sharing. The willingness depends on personal motivations, beliefs, as well as organizational culture (Bock et al., 2005; Lin, 2011; Yi, 2009). The knowledge diffusion activities can be stimulated by means such as reward and performance evaluation system (Huang et al., 2007).

Gupta and Govindarajan (2000) presented in their article that diffusion of knowledge consists of five elements: 1. perceptions as to the value of the source knowledge; 2 . the willingness of the source to share that knowledge; 3 . the availability of rich information channels; 4 . the willingness of the recipient to acquire the knowledge; and 5. the absorptive capacity of the recipient.

Different means can be used to diffuse knowledge in an organization such as for example: training, mentoring, project discussion, team meeting (Manohar Singh \& Gupta, 2014) and social media. In literature, the importance of knowledge diffusion is highlighted by Argote and Ingram (2000) as well as Cummings and Teng (2003) who linked it to the competitive advantages of an organization, the capabilities of innovation, and productivity.

\section{Knowledge Application}

The main aim of knowledge management is to ensure the knowledge present in an organization is applied productively (Probst, Raub, \& Romhardt, 2000). According to definition presented by Bhatt (2001), "knowledge application means making knowledge more active and relevant for the firm in creating value" (pp. 72-73).

The application of knowledge can consist of using knowledge to solve new problems, applying stored knowledge to improve efficiency, linking sources of knowledge to problems, using knowledge to adjust strategic direction, using knowledge from past mistakes. Knowledge 
application can be seen in terms of the type or amount of learning in the difference between knowledge exploration and exploitation (March, 1991; Gupta, Smith, \& Shalley, 2006).

\section{Knowledge Storage}

Knowledge storage is one of the very important processes. Alavi and Leidner (2001) insisted that creating new knowledge is not enough because people forget, and mechanisms are needed to store acquired knowledge and to retrieve it when needed. Otherwise, an organization is constantly in danger of accidentally losing the gained knowledge (e.g. Stein \& Swass, 1995).

It is important to deepen the understanding of knowledge storage through explaining organizational memory which can be defined as a system of knowledge and skills that preserve as well as stores perceptions and experiences beyond the moment when they occur so that they can be retrieved at a later time (Wiig, 1993). Organizational memory includes knowledge residing in various forms, such as written documents, electronic databases, codified knowledge in expert systems, documented organizational procedures and processes, as well as tacit knowledge located in individuals and networks of individuals (Alavi \& Leidner, 2001).

According to Walsh and Ungson (1991), organizational memory includes a memory of an individual (observations, intuition, experiences, \& actions), organizational culture, transformations (production processes \& work procedures), organizational structure (roles), ecology (physical work setting), as well as internal and external information archives. Bhatt (2001) underlined that an organization will struggle to retain its competitive advantages if the needed knowledge has not been made easily available in right kind of a format. Nowadays, also the safety and privacy issue are very important. Organizations should implement securityoriented technologies that restrict access to organizational knowledge (Gold, Malhotra, \& Segars, 2001). Especially, the knowledge should be protected from inappropriate use or being leaked and the access should be restricted to some source of knowledge. Managers should communicate the importance of knowledge protection throughout the organization.

\section{Organizational Culture}

Organizational culture is the set of values, beliefs, norms, meanings, and practices shared by personnel within an organization (Cowan \& Harrison, 2004). Hofstede (1980) defined national culture as the collective programming of the mind that distinguishes the members of one group or category of people from another. The collective programming is possible when people lived within the same social environment where it is learned. Culture is expressed through symbols, heroes, rituals, and concepts. Hofstede (1980), in his research, proposed five dimensions of national culture: 1 . power distance (the tolerance for power disparity in society); 2 . uncertainty avoidance (the tolerance for uncertainty, ambiguity, risk, \& the need for formal rules); 3. individualism-collectivism (how much a given individual puts his/her interests ahead of those of the group to which he or she belongs); 4. masculinity-femininity (the emphasis on clear distinctions between emotional gender roles); and 5. time horizon (whether a person is short-term oriented or longer-term oriented).

The concept of culture is complex topic, which evolved throughout the time. At the beginning, the concept was defined from a sociological and anthropological perspective. As Schein (2004) suggested culture was related to "the customs and rituals developed by societies over the course 
of their history" (p. 7). Later, this concept got another perspective once managers and researchers started to use it in area of management. In the context of knowledge management, organizational culture can be defined as a complex collection of values, beliefs, behaviors, and symbols that influences knowledge management in organizations (Ho, 2009). According to Mavondo and Farrell, (2003) organizational culture is related to how people respond to a situation and how the environment is interpreted. Organizational culture is also known to influence organizational performance. According to study presented by Kotter and Heskett (1992), the most financially successful companies had cultures that strove to serve customers, employees, and stockholders, instead of just one or two of these. They studied 207 companies using questionnaires, interviews, financial analysis, and observation (Kotter \& Heskett, 1992).

Many researchers confirmed the causal link between organizational culture and knowledge management (Davenport \& Prusak, 1998; Gold et al., 2001; Alavi, Kayworth, \& Leidner, 20052006; Paliszkiewicz, 2007). An effective organizational culture can encourage knowledgerelated activities by creating suitable environments for knowledge accessibility (Janz \& Prasarnphanich, 2003). According to Alavi and Leidner (2001), a collaborative environment creates opportunities for knowledgeable people to share knowledge openly and have more successful knowledge management programs. In this study, we were interested in assessing the role of knowledge management processes in association with organizational culture.

\section{Knowledge Management and Organizational Culture - Results of the Research}

\section{Purpose of the Study}

The purpose of this study was to investigate which of the four predictor variables (applying knowledge, storing knowledge, acquiring knowledge, \& diffusing knowledge) is most significantly associated with Organizational Culture.

\section{Research Question}

Which of the four predictor variables (applying knowledge, storing knowledge, acquiring knowledge, \& diffusing knowledge) is most significantly associated with Organizational Culture?

\section{Methodology}

\section{Instrument}

The instrument for this study consisted of five parts, that were used to measure four knowledge management processes (knowledge acquisition, knowledge storage, knowledge diffusion, knowledge application, \& organizational culture). The instrument was prepared by Remy Magnier-Watanabe and Caroline Benton from the University of Tsukuba in Tokyo and was a part of Global Knowledge Survey. Knowledge management processes (knowledge acquisition, knowledge diffusion, knowledge application, \& knowledge storage) were measured in five dimensions: 
- Intention;

- Autonomy;

- Fluctuation and creative chaos;

- Redundancy;

- Requisite variety.

It included the following 5-point Likert-scale: $1=$ of very little or no importance, $2=$ of little importance, $3=$ of moderate importance, $4=$ very important, $5=$ of utmost importance.

Organizational culture measure comprised of eight items. It included the following 5-point Likert-scale: 1 = extremely incorrect, $2=$ somewhat incorrect, $3=$ neither true nor incorrect, $4=$ somewhat trust, $5=$ extremely true. The items comprised of the Organizational Culture measures were:

1. The organization encourages employees and managers to interact with colleagues other than their direct co-workers in order to gather relevant information.

2. The organization promotes the initiative in collecting information and data at the source.

3. Important information within your department has been compiled into databases or servers and can be accessed freely.

4. Systems are in place for sharing information at the company level even if that information is not needed immediately.

5. The organization leaves the diffusion of information and knowledge to the initiative of both employees and managers, based on necessity.

6. Information coming from managers is mostly communicated informally based on the needs of the situation.

7. The organization frequently re-examines existing processes and taken-for-granted viewpoints.

8. The organization expects a high degree of originality and initiative from employees and managers to perform their work.

\section{Sample Population and Procedure}

The survey was made available during February and March, 2016. The instrument was administered face-to-face to 150 individuals. There were 120 survey participants, but because some of them were incomplete, 77 usable survey records remain for further analysis. The participants were from two large cities in Georgia: Tbilisi and Kutaisi, where the majority of Georgia's economical activity is concentrated. The sample included 22 males (29\%) and 55 females (71\%). All participants were over the age of 20 (36\% - 20-29 years old, 35\% - 30-39 years old, $21 \%$ - 40-49 years old, \& 9\% over 50 years old). Most of the participants had a master degree $-75 \%, 21 \%$ had the 4-year degree and 4\% - had the 2-year degree. Participants gave following answers for the question "What is the level of the paid job you currently have?"

1. No paid job (includes full-time students) $-4 \%$

2. Unskilled or semi-skilled manual worker $-3 \%$

3. Generally trained office worker or secretary $-16 \%$

4. Vocationally trained craftsperson, technician, or equivalent $-1 \%$ 
5. Academically trained professional or equivalent (but not a manager of people) $44 \%$

6. Manager of one or more subordinates (non-managers) $-23 \%$

7. Manager of one or more managers $-9 \%$

The participants were assured confidentiality and anonymity.

\section{Data Analysis}

Multiple regression analysis was used to answer the research question, via the Enter method, where all independent variables (IVs) enter into the model one at a time. The analysis was conducted to determine which of the independent variables (IV_1 = Acquiring Knowledge, IV_2 = Storing Knowledge, IV_3 = Diffusing Knowledge, \& IV_4 = Applying Knowledge) has the highest weight when predicting the dependent variable (DV = Organizational Culture).

Multiple regression analysis produces a coefficient table that shows the Beta weights, t-values, and p-values for the independent variables (the predictor variables) in predicting the dependent variable. Steven (2001) stated that prior to interpreting the coefficient table, the following analyses should be carried out:

1) Determining the non-existence of multicollinearity among the IVs -- the tolerance level values for all IVs should be above .1, and the (VIF) values for all IVs should not be greater than 10 .

2) Examining the model summary -- $\left(R, R^{2}, \& R^{2}{ }_{a d j}\right)$-- pointing to how well the IVs predict the DV.

3) Investigating the Analysis of Variance (ANOVA) table -- showing the F-test and the level of significance. If the F-test is significant, then the relationship between the DV and the IVs is linear, therefore, the model significantly predicts the DV.

\section{Results}

Table 1 shows the regression model's tolerance level that determines the non-existence of multicollinearity among the IVs in this study. As seen, the tolerance level values for all IVs are well above .1 and the VIF values for all IVs are less than 10. These values demonstrate the nonexistence of multicollinearity among the IVs.

Table 1. Regression Model's Tolerance Level $(\mathrm{N}=77)$

\begin{tabular}{|l|l|l|l|}
\hline & & Tolerance & VIF \\
\hline 1 & (Constant) & & \\
\cline { 2 - 4 } & Acquiring & .549 & 1.822 \\
\cline { 2 - 4 } & Storing & .598 & 1.673 \\
\hline \multirow{2}{*}{ Diffusing } & .544 & 1.837 \\
\cline { 2 - 4 } & Applying & .593 & 1.685 \\
\hline
\end{tabular}

Table 2 shows the model summary $\left(\mathrm{R}=.484, \mathrm{R}^{2}=.234, \& \mathrm{R}_{\text {adj }}^{2}=.191\right)$. These values point to the reasonably acceptable values that indicate how well the IVs predict the DV. 


\begin{tabular}{|c|c|c|c|c|}
\hline \multicolumn{5}{|c|}{ Table 2. Model Summary $(\mathrm{N}=77)$} \\
\hline Model & $\mathbf{R}$ & R Square & Adjusted R Square & $\begin{array}{l}\text { Std. Error of the } \\
\text { Estimate }\end{array}$ \\
\hline 1 & $.484^{\mathrm{a}}$ & $\begin{array}{l}.23 \\
4\end{array}$ & .191 & .61534 \\
\hline
\end{tabular}

a. Predictors: (Constant), Applying, Storing, Acquiring, and Diffusing

The ANOVA table is shown in Table 3. As can be seen, the F-test and the level of significance. If the F-value is significant $(\mathrm{p}=.001)$ indicating that the relationship between the IVs and the DV is linear.

Table 3. ANOVA ${ }^{\text {a }}$ for the Multiple Regression Model $(\mathrm{N}=77)$

\begin{tabular}{|l|ll|l|l|l|l|}
\hline Model & & Sum of Squares & df & Mean Square & F & Sig. \\
\hline \multirow{1}{*}{1} & Regression & 8.323 & 4 & 2.081 & 5.496 & $\mathbf{. 0 0 1}^{\boldsymbol{b}}$ \\
\cline { 2 - 7 } & Residual & 27.262 & 72 & .379 & & \\
\cline { 2 - 7 } & Total & 35.585 & 76 & & & \\
\hline
\end{tabular}

a. Dependent Variable: Organizational Culture

b. Predictors: (Constant), Applying, Storing, Acquiring, and Diffusing

Table 4 shows the coefficients and includes the Beta weights, t-values, and p-values for the IVs (the predictor variables) that were entered the analysis in predicting the DV. As can be seen IV_1 = Acquiring Knowledge, IV_2 = Storing Knowledge, and IV_4 = Applying Knowledge were not significant $(\mathrm{p}=0.334,0.071, \& 0.828$ respectively) variables in predicting the $\mathrm{DV}$, i.e. Organizational Culture. However, IV_3 = Diffusing Knowledge was found to be significant $(\mathrm{p}=0.005)$ in predicting the DV Organizational Culture. Tables 5 and 6 show the correlations and descriptive statistics.

Table 4. Coefficients ${ }^{\mathrm{a}}$ Table of the Multiple Regression Model ( $\left.\mathrm{N}=77\right)$

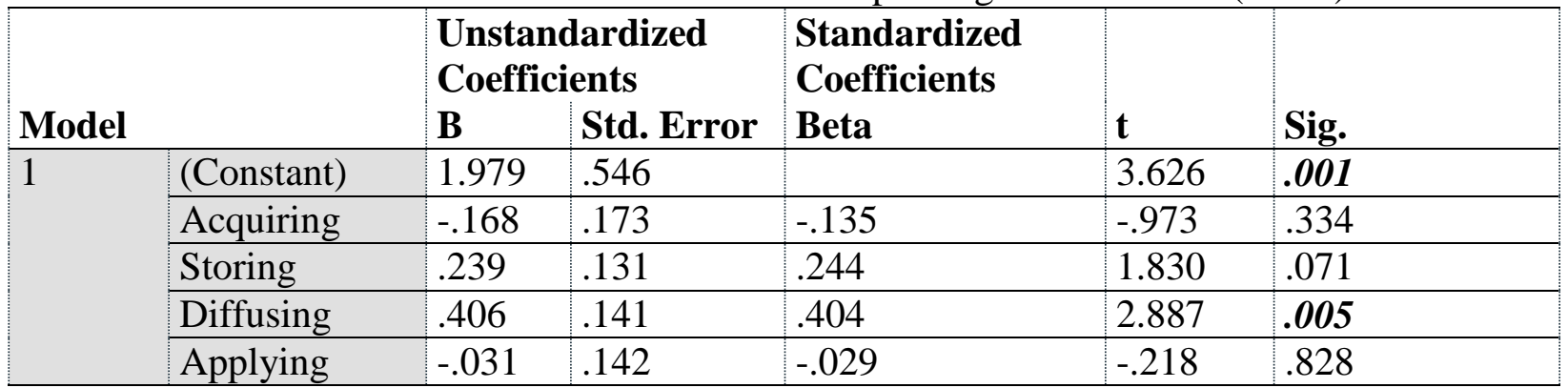

a. Dependent Variable: Organizational Culture 


\begin{tabular}{|lllllll}
\hline \multicolumn{7}{c}{ Table 5. Correlation Table (N=77) } \\
\hline \multirow{2}{*}{$\begin{array}{l}\text { Pearson } \\
\text { Correlation }\end{array}$} & Org. Culture & Acquiring & Storing & Diffusing & Applying \\
\cline { 2 - 7 } & Org. Culture & 1.000 & .202 & .365 & .443 & .234 \\
\cline { 2 - 7 } & Acquiring & .202 & 1.000 & .579 & .524 & .524 \\
\cline { 2 - 7 } & Storing & .365 & .579 & 1.000 & .524 & .402 \\
\cline { 2 - 7 } & Diffusing & .443 & .524 & .524 & 1.000 & .584 \\
\cline { 2 - 7 } & Applying & .234 & .524 & .402 & .584 & 1.000 \\
\hline \multirow{3}{*}{ Sig. (1-tailed) } & Org. Culture &. & .039 & .001 & .000 & .020 \\
\cline { 2 - 7 } & Acquiring & .039 & .000 & .000 & .000 & .000 \\
\cline { 2 - 7 } & Storing & .001 & .000 & .000 & .000 \\
\cline { 2 - 7 } & Diffusing & .000 & .000 & .000 & .000 & .000 \\
\cline { 2 - 7 } & Applying & .020 & .000 & .000 & .000 &. \\
\cline { 2 - 7 } & & & .000 & & .000 & \\
\hline
\end{tabular}

Table 6. Descriptive Statistics of the Variables $(\mathrm{N}=77)$

\begin{tabular}{lll}
\hline & Mean & $\begin{array}{l}\text { Std. } \\
\text { Deviation }\end{array}$ \\
\hline Organizational Culture & 3.648 & .684 \\
\hline Acquiring & 3.842 & .552 \\
\hline Storing & 3.694 & .699 \\
\hline Diffusing & 3.826 & .680 \\
\hline Applying & 3.935 & .647 \\
\hline
\end{tabular}

\section{Discussion and Conclusion}

Nowadays, knowledge is a very important resource for business organizations, and it has become one of the most important components of all products and services (Gürdal \& Kumkale, 2014). A large number of studies have been made on the processes of knowledge management (LeonardBarton, 1995; Liebowitz, 1999; Nonaka \& Takeuchi, 1995; Paliszkiewicz, 2007; Paliszkiewicz, 2015; Pietrzak, Paliszkiewicz, Jałosiński, \& Brzozowski, 2015).

The present study aimed to examine which of the four variables (applying knowledge, storing knowledge, acquiring knowledge, and diffusing knowledge) is most significantly associated with Organizational Culture. Multiple regression analysis was used to realize the aim of the study. According to the analysis Diffusing Knowledge was found to be significant associated with the Organizational Culture.

Knowledge needs to be managed in order to provide organizations benefits (Gürdal \& Kumkale, 2014). Knowledge diffusion is one of the knowledge management processes contributing to the organization's success. The atmosphere created during this process appears to have a significant role, to a great extent, in possible affecting the organizational culture. Most of the studies underline that organizational culture is considered as an important factor, which appear to have a role on the success of knowledge sharing (Chakravorti, 2011; De Long \& Fahey, 2000; Gold et al., 2001; Gürdal \& Kumkale, 2014). Nevertheless, many scholars fail to close the gap in comprehending the role of diffusion of knowledge on organizational culture. 
Today, the development of Internet and social media has changed a lot the possibilities of knowledge diffusion. The World Wide Web's role in information retrieval has proved that this tool is highly effective for knowledge sharing (Sambamurthy, Bharadwaj, \& Grover, 2003; Goh, 2004). The Internet enables to diffuse knowledge around the world, without any boundaries and limited cost (Marwick, 2001). Social media expedites contact between employees who seek knowledge and those who possess it. The development of these technologies appears to have a role on the way people contact one another and how often they communicate. All of these aspects has a role on the atmosphere in the workplace, on the level of stress, and in many ways, appear to influence organizational culture.

This study has limitations. A convenient sample was used with subjects from only one country. To increase the generalizability of the results, we recommend that this study should be expanded to include population sample from different countries and wider geographic areas. The study's methodology also minimizes the ability to claim causality regarding the predictable impact of knowledge processes on organizational culture. We recommend future studies to be design to account for such an effect. Further reseach is required to continue investigating the findings of this research, as it may create a better understanding of the role of knowledge diffusion (\& other knowledge processes) in organizational culture and their link with organizational performance. Based on the review of the articles and the results of this paper, future studies can also be conducted to survey motivations and barriers of an organizational knowledge diffusion especially with using social media; to diffuse knowledge from universities to research centers or industries; and to develop protection of the key knowledge inside the organization.

\section{References}

Al Saifi, S. A. (2015). Positioning organisational culture in knowledge management research. Journal of Knowledge Management, 19(2), 164-189.

Alavi, M., \& Leidner, D. E. (1999). Knowledge management systems: issues, challenges and benefits. Communications of the AIS, 1(7), 1-37.

Alavi, M., \& Leidner, D. E. (2001). Review: Knowledge management and knowledge management systems: conceptual foundations and research issues. MIS Quarterly, 25(1), 107-136.

Alavi, M., Kayworth, T. R., \& Leidner, D. E. (2005-2006). An empirical examination of the influence of organizational culture on knowledge management practices. Journal of Management Information Systems, 22(3), 191-224.

Amiryany, N., Huysman, M., Ard-Pieter, d. M., \& Cloodt, M. (2012). Acquisition reconfiguration capability. European Journal of Innovation Management, 15(2), 177-191.

Andreeva, T., \& Kianto, A. (2011). Knowledge processes, knowledge-intensity and innovation: A moderated mediation analysis. Journal of Knowledge Management, 15(6), 1016-1034.

Argote, L., \& Ingram, P. (2000). Knowledge transfer: A basis for competitive advantage in firms. Organizational Behavior and Human Decision Processes, 82(1), 150-169.

Argyris, C., \& Schon, D. (1978). Organizational learning. Reading, MA: Addison-Wesley. 
Bhatt, G. D. (2001). Knowledge management in organizations: Examining the interaction between technologies, techniques, and people. Journal of Knowledge Management, 5(1), $68-75$

Bock, G. W., Zmud, R. W., \& Kim, Y. G. (2005). Behavioral intention formation in knowledge sharing: examining the roles of extrinsic motivators, socio-psychological forces and organisational climate. MIS Quarterly, 29(1), 87-111.

Bozorgi, F., Khalili, M. R., \& Khalili, M. A. (2013). Effect of organizational factors on knowledge management in education: A case study in mazandaran province, departments of education. European Online Journal of Natural and Social Sciences, 2(4), 531-540

Bresman, H., Birkinshaw, J., \& Nobel, R. (2010). Knowledge transfer in international acquisitions. Journal of International Business Studies, 41, 5-20.

Chakravorti, S. (2011). Managing organizational culture change and knowledge to enhance customer experiences: Analysis and framework. Journal of Strategic Marketing, 19(2), 123-151.

Cowan, R., \& Harrison, E. (2004). On substitution of intellectual property and free disclosure: An analysis of R\&D strategies in software technologies. Economics of Innovation and New Technology, 13(5), 477-487.

Cummings, J. L., \& Teng, B. S. (2003). Transferring R\&D knowledge: The key factors affecting knowledge transfer success. Journal of Engineering and Technology Management, 20(12), 39-68.

Davenport, T. H., \& Volpel, S. C. (2001). The rise of knowledge towards attention management. Journal of Knowledge Management, 5(3), 212-221.

Davenport, T. H., \& Prusak, L. (1998). Working knowledge. Boston, MA: Harvard Business School.

De Long, D., \& Fahey, L. (2000). Diagnosing cultural barriers to knowledge management. Academy of Management Executive, 14(4), 113-127.

Dilmaghani, M., Fahimnia, F., Ardakan, M. A., \& Naghshineh, N. (2015). Function of knowledge culture in the effectiveness of knowledge management procedures: A case study of a knowledge-based organization. Webology, 12(1), 1-21.

Dixon, N. M. (2000). Common knowledge: How companies thrive by sharing what they know. Boston, MA: Harvard Business School Press.

Drucker, P. (1993). Post-capitalist society. London, United Kingdom: Butterworth Heinemann.

Drucker, P. F. (2001), The essential drucker: The best of sixty years of Peter Drucker's essential writings on management. New York, NY: HarperCollins Business.

Duncan, R., \& Weiss, A. (1979). Organizational learning: A theory of action perspective. Boston, MA: Addison-Weslay.

Fiol, M., \& Lyles, M. (1985). Organizational learning. Academy of Management Review, 10, 803-813. 
Fong, P. S. W., \& Choi, S. K. Y. (2009). The processes of knowledge management in professional services firms in the construction industry: A critical assessment of both theory and practice. Journal of Knowledge Management, 13(2), 110-126.

Fong, P. S. W., \& Lee, H. F. (2009). Acquisition, reuse and sharing of knowledge in property management firms. Facilities, 27(7/8), 291-314.

Gilbert, M., \& Cordey-Hayes, M. (1996). Understanding the process of knowledge transfer to achieve successful technological innovation. Technovation 16(6), 301-312.

Goh, A. (2004), Enhancing organisational performance through knowledge innovation: A proposed strategic management framework. Journal of Knowledge Management Practice, 5(1), 111-123.

Gold, A. H., Malhotra, A., \& Segars, A. H. (2001). Knowledge management: An organizational capabilities perspective. Journal of Management Information Systems, 18(1), 185-214.

Gupta, A. K., \& Govindarajan, V. (2000). Knowledge flows within multinational corporations. Strategic Management Journal, 21(4), 473-496.

Gupta, A. K., Smith, K. G., \& Shalley, C. E. (2006). The interplay between exploration and exploitation. Academy of Management Journal, 49, 693-706.

Gürdal, S. A., \& Kumkale, I. (2014). The relationship between organizational culture and knowledge sharing: Kirklareli sample of manufacturing sector. IIB International Refereed Academic Social Sciences Journal, 5(16), 19-45.

Ho, C. (2009). The relationship between knowledge management enablers and performance. Industrial Management \& Data Systems, 109(1), 98-117.

Hofstede, G. (1980). Culture's consequences: International differences in work-related values. Beverly Hills, CA: Sage Publications.

Howells, J. (1996). Tacit knowledge, innovation and technology transfer. Technology Analysis and Strategic Management, 8(2), 91-106.

Huang, N., Chiu-Chi, W., \& Wei-Kou, C. (2007). Knowledge management: Modeling the knowledge diffusion in community of practice. Kybernetes, 36(5), 607-621.

Huber, G. (1991). Organizational learning: The contributing processes and literatures. Organization Science, 2(1), 88-115.

Inkpen, A. C., Sundaramanant, K., \& Rockwood, K. (2000). Cross-border acquisitions of US technology assets. California Management Review, 42(3), 50-71.

Janz, B. D., \& Prasarnphanich, P. (2003). Understanding the antecedents of effective knowledge management: The importance of a knowledge-centered culture. Decision Sciences, 34(2), 351-384.

Kim, S., \& Lee, H. (2010). Factors affecting employee knowledge acquisition and application capabilities. Asia-Pacific Journal of Business Administration, 2(2), 133-152. 
Koohang, A., Paliszkiewicz, J., \& Gołuchowski, J., (2017 - in press). The impact of leadership on trust, knowledge management, and organizational performance: A research model. Industrial Management and Data Systems.

Kotter, J. P. \& Heskett, J. L. (1992), Corporate culture and performance. New York, NY: Free Press.

Leonard-Barton, D. (1995). Wellsprings of knowledge. Boston, MA: Harvard Business School Press.

Liao, S., Wu, C., Hu, D., \& Tsui, K. (2010). Relationships between knowledge acquisition, absorptive capacity and innovation capability: An empirical study on Taiwan's financial and manufacturing industries. Journal of Information Science. 36(1), 19-35.

Liebowitz, J. (1999). Key ingredients to the success of an organization's knowledge management strategy. Knowledge and Process Management, 6(1), 37-40.

Liebowitz, J. (ed.) (2008). Making cents out of knowledge management. Lanhman, MD: The Scarecrow Press, INC.

Liebowitz, J. (ed.) (2012). Knowledge management handbook. Collaboration and social networking. New York, NY: CRC Press, Taylor and Francis Group.

Liebowitz, J. (ed.) (2016). Successes and failures of knowledge management. Cambridge MA: Elsevier.

Lin, H. F., \& Lee, G. G. (2006). Effects of socio-technical factors on organisational intention to encourage knowledge sharing. Management Decision, 44(1), 74-88.

Lin, H. F. (2011). Antecedents of the stage-based knowledge management evolution. Journal of Knowledge Management, 15(1), 136-55.

Liu, J. Y. (2010). Study on the impact of firm size on patterns of knowledge acquisition. Proceedings of the Fifth International Conference on Management and Service Science, Wuhan.

Liu, M. S., \& Liu, N. C. (2008). Sources of knowledge acquisition and patterns of knowledgesharing behaviors: an empirical study of Taiwanese high-tech firms. International Journal of Information Management, 28(5), 423-432.

Lopez, P., Peon, J., \& Ordas, C. (2004). Managing knowledge: The link between culture and organizational learning. Journal of Knowledge Management, 8(6), 93-104.

Lyles, M. A., \& Schwenk, C. R. (1992). Top management, strategy and organizational knowledge structures. Journal of Management Studies 29(2), 155-174.

Lyles, M. A., \& Salk, J. E. (2007). Knowledge acquisition from foreign parents in international joint ventures: An empirical examination in the Hungarian context. Journal of International Business Studies, 38(1), 3-18.

Magnier-Watanabe, R., \& Senoo, D. (2010). Shaping knowledge management: Organization and national culture. Journal of Knowledge Management, 14(2), 214-227. 
Manohar Singh, R., \& Gupta, M. (2014). Knowledge management in teams: Empirical integration and development of a scale. Journal of Knowledge Management, 18(4), 777794.

March, J. (1991). Exploration and exploitation in organizational learning. Organization Science, 2, 71-87.

Marwick, D. (2001). Knowledge management technology. IBM Systems Journal, 40(4), 814-830.

Mavondo, F., \& Farell, M. (2003). Cultural orientation: Its relationship with market orientation, innovation and organizational performance. Management Decision, 41(3), 241-249.

McDermott, R., \& O’Dell, C. (2001). Overcoming culture barriers to sharing knowledge. Journal of Knowledge Management, 5(1), 76-85.

Nonaka, I. (1994). A dynamic theory of organizational knowledge creation. Organization Science 5(1), 14-37.

Nonaka, I., \& Takeuchi, H. (1995). The knowledge creating company. New York, NY: Oxford University Press.

Paliszkiewicz, J. (2007). Zarządzanie wiedza w małych i średnich przedsiębiorstwach koncepcja oceny i modele, [Knowledge management in small and medium enterprises concept of estimating and models] Wydawnictwo SGGW, Warszawa 2007.

Paliszkiewicz, J., \& Koohang, A. (2013). Organizational trust as a foundation for knowledge sharing and its influence on organizational performance. Online Journal of Applied Knowledge Management, 1(2), 116-127.

Paliszkiewicz, J., Gołuchowski, J., \& Koohang A. (2015). Leadership, trust, and knowledge management in relation to organizational performance: Developing an instrument. Online Journal of Applied Knowledge Management, 3(2), 19-35.

Pietrzak, M., Paliszkiewicz, J., Jałosiński, K., \& Brzozowski, A. (2015). A case study of strategic group map application used as a tool for knowledge management. Journal of Computer Information Systems, 55(2), 68-77.

Prahalad, C. K., \& Bettis, R. A. (1986). The dominant logic: A new linkage between diversity and performance. Strategic Management Journal 7(6), 485-501.

Probst, G., Raub, S., \& Romhardt, K. (2000). Managing knowledge - Building blocks for success. Chichester, England: Wiley.

Puranam, P., Singh, H., \& Zollo, M. (2003). A bird in the hand or two in the bush? Integration trade-offs in technology-grafting acquisitions. European Management Journal, 21, 17984.

Rai, R. K. (2011). Knowledge management and organizational culture: A theoretical integrative framework. Journal of Knowledge Management, 15(5), 779-801.

Rusly, F. H., Corner, J. L., \& Sun, P. (2012). Positioning change readiness in knowledge management research. Journal of Knowledge Management, 16(2), 329-355. 
Ryu, C., Kim, Y. J., Chaudhury, A., \& Rao, H. R. (2005). Knowledge acquisition via three learning processes in enterprise information portals: Learning-by-investment, learningby-doing, and learning-from-others. MIS Quarterly, 29(2). 245-278.

Sambamurthy, V., Bharadwaj, A., \& Grover, V. (2003). Shaping agility through digital options: Reconceptualising the role of information technology in contemporary firms. MIS Quarterly, 27(2), 237-263.

Schein, E. (2004). Organizational culture and leadership. San Francisco, CA: Jossey Bass.

Shveiby, K. E. (1987). Managing knowhow. London, UK: Bloomsbury.

Stacey, R. D. (2000). The emergence of knowledge in organization. Emergence, 2(4), 23-39.

Stein, E. W., \& Swass, V. (1995). Actualizing organizational memory with information systems. Information Systems Research, 6(2), 85-117.

Tseng, S. M. (2010). The effects of hierarchical culture on knowledge management processes. Management Research Review, 33(8), 827-839.

Vermeulen, F., \& Barkema, H. (2001). Learning through acquisitions. The Academy of Management Journal, 44, 457-476.

Von Krogh, G,, Ichijo, K., \& Nonaka, I. (2000). Enabling knowledge creation: How to unlock the mystery of tacit knowledge and release the power of innovation. New York, NY: Oxford University Press.

Von Krogh, G., \& Roos, J. (1995). Organizational epistemology. New York, NY: St. Martin’s Press.

Walsh, J. P., \& Ungson, G. R. (1991). Organizational memory. Academy of Management Review, $16(1), 57-91$.

Wiig, K. (1993). Knowledge management foundations: Thinking about thinking-how people and organizations create: Represent and use knowledge. Arlington, TX: Schema Press.

Yang, S. C., \& Farn, C. K. (2010). Investigating tacit knowledge acquisition and sharing from the perspective of social relationships - a multilevel model. Asia Pacific Management Review, 15(2), 167-185.

Yi, J. (2009). A measure of knowledge sharing behaviour: Scale development and validation. Knowledge Management Research and Practice, 7(1), 65-81.

Zheng, W. (2009). The knowledge-inducing culture: An integrative framework of cultural enablers of knowledge management. Journal of Information and Knowledge Management, 8 (3), 213-227. 


\section{Authors' Biographies}

Joanna Paliszkiewicz is a specialist in management issues connected with knowledge management, intellectual capital and trust management. She holds the rank of University Professor of Warsaw University of Life Sciences and Polish-Japanese Academy of Information Technology. Prof. J. Paliszkiewicz is well recognized in Poland and abroad with her expertise in management issues. She has published over 150 original papers and four books. She serves on the editorial board of several international journals. She is the deputy editor-in-chief of Management and Production Engineering Review Journal. Prof. J. Paliszkiewicz has been awarded a number of grants sponsored by Polish Ministry of Sciences. In recognition in her outstanding teaching and research, Professor J. Paliszkiewicz has been the recipient of the two awards of excellence from the Rector of the Warsaw University of Life Sciences. Dr. Paliszkiewicz was named the 2013 Computer Educator of the Year by IACIS.

Salome Svanadze has a B.Sc. degree in the field of Management and Economics, and holds a M.Sc. in Economics from the Faculty of Economics, Georgian State University. She is currently working on her Ph.D. in Business Administration at the Faculty of Business at Ilia State University, Georgia after two years of study exchange at Warsaw University of Life Sciences. Considering over five years of working experience for the Investment Funds at emerging markets, her research and teaching interests consist of intellectual capital, creating economic opportunities (particularly utilizing opportunities at emerging markets) as well as phenomena of knowledge and trust management of leadership in enterprises.

Mariam Jikia holds a Ph.D. in Law from Georgian Technical University, MPA from Georgian Institute of Public Affairs, and Master of Law from Ivane Javakhishvili Tbilisi State University. Dr. Dikia is an Associate Professor at the Georgian Technical University, invited Professor at Ilia State University, and Ivane Javakhishvili Tbilisi State University; Head of Research Institute of International Law at Caucasus International University. Dr. Jikia is an author of several monographs and original research papers. Dr. Jikia has conducted her Post-Doctoral research at the University of Basque Country, along with a Max-Plank and DAAD Research fellowships. Dr. Jikia worked as a visiting scholar in Max-Plank Institute of Comparative and Public International Law (Heidelberg) and the University of Regensburg, Germany. 